\title{
Canadian Journal of Microbiology
}

Revue canadienne de microbiologie

\section{Effects of reclamation years on composition and diversity of soil bacterial communities in Northwest China}

\begin{tabular}{|r|l|}
\hline Journal: & Canadian Journal of Microbiology \\
\hline Manuscript ID & cjm-2017-0362.R2 \\
\hline Date Submitted by the Author: & 21-Sep-2017 \\
\hline Complete List of Authors: & $\begin{array}{l}\text { Cheng, Zhibo; Shihezi University College of Agriculture } \\
\text { Zhang, Fenghua; Shihezi University College of Agriculture } \\
\text { Gale, William Jeffrey; Agricultural College } \\
\text { Wang, Weichao; Agricultural College } \\
\text { Sang, Wen; Agricultural college } \\
\text { Yang, Haichang; Shihezi University College of Agriculture }\end{array}$ \\
\hline $\begin{array}{r}\text { Is the invited manuscript for } \\
\text { consideration in a Special } \\
\text { Issue? : }\end{array}$ & N/A \\
\hline Keyword: & $\begin{array}{l}\text { Abandoned farmland, Reclamation time, Soil aggregates, Bacterial } \\
\text { community, Illumina sequencing }\end{array}$ \\
\hline \multicolumn{2}{|c}{} \\
\hline \multicolumn{2}{|c|}{} \\
\hline
\end{tabular}




\title{
Effects of reclamation years on composition and diversity of soil bacterial communities in Northwest China
}

\author{
Zhibo Cheng, Fenghua Zhang, William Jeffrey Gale, Weichao Wang, Wen Sang, \\ and Haichang Yang
}

College of Agronomy, Shihezi University, Xinjiang Province 832003, China

* Corresponding author: Fenghua Zhang (email: zhangfenghua6088@126.com).

\author{
Fenghua Zhang \\ Agricultural College, Shihezi University, Shihezi City, 832003, China \\ Phone: +86-13519926088 \\ Email: zhangfenghua6088@126.com
}

https://mc06.manuscriptcentral.com/cjm-pubs 
Abstract: The objective of this study was to evaluate bacterial community structure and diversity in soil aggregate fractions when salinized farmland was reclaimed after $>27 \mathrm{yr}$ of abandonment and then farmed again for 1, 5, 10, and 15 yr. Illumina MiSeq high-throughput sequencing was performed to characterize the soil bacterial communities in five aggregate size classes in each treatment. The results indicated that reclamation significantly increased macro-aggregation $(>0.25 \mathrm{~mm})$, as well as soil organic C, available N, and available P. The 10-yr field had the largest proportion (93.9\%) of soil in the macro-aggregate size classes (i.e., $>0.25 \mathrm{~mm}$ ) and the highest soil electrical conductivity. The five most dominant phyla in the soil samples were Proteobacteria, Actinobacteria, Gemmatimonadetes, Acidobacteria, and Bacteroidetes. The phylogenetic diversity, Chao1, and Shannon indices increased after the abandoned land was reclaimed for farming, reaching maximums in the 15-yr field. Among aggregate size classes, the $1-0.25 \mathrm{~mm}$ aggregates generally had the highest phylogenetic diversity, Chao1, and Shannon indices. Soil organic C and soil electrical conductivity were the main environmental factors affecting the soil bacterial communities. The composition and structure of the bacterial communities also varied significantly depending on soil aggregate size and time since reclamation.

Key words: Abandoned farmland, reclamation time, soil aggregates, bacterial community, Illumina sequencing.

\section{Introduction}

Soils are highly complex, heterogeneous environments which play an important role in selecting the resident microbial community (O'Donnell et al. 2007; Torsvik \& Øvreås 2002; Soman et al. 2016). Bacteria are the most abundant and diverse group of soil microorganisms (Gans et al. 2005). As primary drivers of $\mathrm{C}, \mathrm{N}$, and $\mathrm{P}$ cycling, bacteria greatly influence the health and sustainability of agroecosystems (Matson et al. 1997; Steenwerth et al. 2002). Many studies have reported that various factors affect soil microbial community membership. These factors include soil properties (Shen et al. 2013; Liu et al. 2015; Nacke et al. 2011), fertilization practices (He et al. 2007, Tian et al. 2017), cropping patterns (Dorrde et al. 2012; Li et al. 2010), and seasonal variation (Schutter et al. 2001; Kennedy et al. 2006). Soil $\mathrm{pH}$ is often a main factor in determining the soil bacterial community (Fierer and Jackson 2006; Rousk et al. 2010).

Soil aggregates are important for maintaining soil porosity and for providing stability against 
erosion (Mikha and Rice 2004; Lupwayi 2001). Soil structure is mainly evaluated by the degree of aggregate stability (Six et al. 2004). Soil bacteria are one of the main agents in aggregate formation and stabilization (Rashid et al. 2016). Knowledge of microbial communities and their activities within different aggregate fractions is limited, but essential for increasing crop production and maintaining agricultural sustainability (Trivedi et al. 2015). Recently developed molecular techniques using rDNA (e.g., Illumina sequencing) are excellent tools for assessing microbial diversity and microbial community composition under different agriculture practices (Nakatsu 2007).

The Manasi River Basin in the Xinjiang Region of northwest China is the country's fourth largest agricultural area. The amount of cultivated land in the basin increased from $156 \mathrm{~km}^{2}$ in 1949 to 6,221 $\mathrm{km}^{2}$ in 2010. In the past, unreasonable irrigation practices destroyed the water-salt balance in many parts of the Manasi River Basin. Intense evaporation caused secondary salinization. Serious ecological problems arose when large areas of farmland were abandoned due to declining productivity (Eynard et al. 2005; Fan et al. 2008). However, large areas of this abandoned farmland have been reclaimed since the introduction of drip irrigation in 2000 .

This work aimed to determine whether soil bacteria communities changed dramatically when salinized farmland was reclaimed after many years of abandonment and how these changes occurred over time. The specific objectives of this study were (i) to identify changes in soil properties and aggregation after abandoned, salinized farmland was reclaimed, (ii) to study the difference in the composition, diversity, and species richness of bacterial communities in different aggregate fractions, and (iii) to identify the environmental factors that significantly influence the bacterial community in soil at different stages in the reclamation process.

\section{Materials and methods}

\section{Site description and design}

The study was conducted at the middle reaches of the Manasi River Basin of Xinjiang, China $\left(44^{\circ} 37^{\prime} \mathrm{N}, 86^{\circ} 08^{\prime} \mathrm{E}, 400 \mathrm{~m}\right.$ above sea level) (Fig. 1). The area has an arid continental climate. The average annual frost-free period is 169 days. The average annual precipitation and evaporation are $153 \mathrm{~mm}$ and 2,005 mm, respectively. Excess flood irrigation in the 1970s and 1980s caused the water table to rise near the soil surface in the area. The salt content of the shallow groundwater was high; thus evaporation led to salt accumulation at the soil surface. Over time, a large area of salinized land 
developed in the basin. More than a quarter of the farmland was eventually abandoned because of salinization.

The experimental site was a $105 \mathrm{hm}^{2}$ area in Shihutan Township. The site had previously been farmed, but then it was abandoned for more than 27 yrs due to soil salinization. The land has been reclaimed for cotton production with drip irrigation and plastic film mulch at different times during the past ten years. The experiment involved five field sites (i.e., treatments): (1) original abandoned farmland (CK, $5 \mathrm{hm}^{2}$ area); (2) 1-yr of cotton production $\left(20 \mathrm{hm}^{2}\right.$ area); (3) 5-yr of cotton production $\left(30 \mathrm{hm}^{2}\right.$ area); (4) 10-yr of cotton production (20 $\mathrm{hm}^{2}$ area); and (5) 15-yr of cotton production (30 $\mathrm{hm}^{2}$ area).

The management practices were the same in all of the cotton fields. The cotton was planted at the end of April each year. The plant density was $2.4 \times 10^{4}$ plants $\mathrm{hm}^{-2}$. The fields were drip-irrigated 8 to 10 times each growing season. Nitrogen $\left(300 \mathrm{~kg} \mathrm{hm}^{-2}\right)$ and phosphorus $\left(200 \mathrm{~kg} \mathrm{hm}^{-2}\right)$ fertilizers were applied via drip irrigation. The total irrigation amount was $4,500 \mathrm{~m}^{3} \mathrm{hm}^{-2} \mathrm{yr}^{-1}$. Calcium superphosphate $\left(450 \mathrm{~kg} \mathrm{hm}^{-2}\right)$ was applied before planting. Cotton gin screenings $\left(2250 \mathrm{~kg} \mathrm{hm}^{-2}\right)$ and cotton residue $\left(6000-\quad 7500 \mathrm{~kg} \mathrm{hm}^{-2}\right.$ ) were returned to the soil each autumn.

The soil at the site is classified as grey desert soil according to the local classification (Gong et al. 1988) and as Yermosol by the FAO-UNESCO system. A soil survey done by the local Soil and Fertilizer Station in 2000 showed no significant spatial variation in the distribution of soil salinity and soil organic matter in the reclamation area. Vegetation on the abandoned farmland is sparse, mainly consisting of Suaeda glauca Bunge, Kalidium foliatum, and Salsola collina Pall. The vegetation was uniformly distributed across the landscape. Grazing was prohibited in the area. Due to the nature of this study, there were no true replications of the different reclamation times. However, considering the uniformity of the soil, vegetation, and climate conditions, we believe that there were no inherent differences among the five field sites at the beginning of the study.

\section{Soil sampling}

Soil sampling was carried out in July 2014 during the bloom period of cotton. Three undisturbed soil samples were collected by randomly digging three pits $(50 \mathrm{~cm}$ width $\times 100 \mathrm{~cm}$ length $)$ at each site. Undisturbed soil samples were removed from the $0-20 \mathrm{~cm}$ depths, and the samples were put in sterilized, hard plastic boxes to maintain the primary structure of the soil. Samples were immediately taken to the lab where three undisturbed soils were combined to form one composite sample per site 
for aggregates fractionation.

The soil samples were sieved according to methods described by Schutter and Dick (2002) and Wei et al. (2014). First, large soil clods were gently broken up by hand, and then the soil samples were spread on brown, sterilized paper to dry slowly for several days until the gravimetric water content reached approximately $80 \mathrm{~g} \mathrm{~kg}^{-1}$ soil. The dry sieving method could be effectively implemented at this moisture level. This process was conducted at $4^{\circ} \mathrm{C}$ to minimize the effect of air drying on the microbial communities and activities.

The dry-sieving method was chosen because it disrupted the physical habitat of microbial communities less than wet-sieving (Schutter and Dick 2002). Fractionation was achieved by placing $100 \mathrm{~g}$ of cold air-dried, sieved soil on nested sieves mounted on a Sieve Shaker (JK-VWS, Shanghai, China). The sieves were mechanically shaken (10 min, amplitude $1.5 \mathrm{~mm}$ ) to separate the soil into the five aggregate fractions $(>5,5-2,2-1,0.25-1$, and $<0.25 \mathrm{~mm})$. Preliminary experiments showed that shaking for $10 \mathrm{~min}$ at $1.5 \mathrm{~mm}$ amplitude was adequate for separating the soil aggregates without destroying the large aggregates. The aggregate distribution was determined by weighing the soil in each aggregate size class. The fractionated samples were later combined to make composite samples for each aggregate size class. The bulk soil and all the soil aggregate samples were stored in sterilized polyethylene bags at $4^{\circ} \mathrm{C}$ until they were analyzed for biological properties and DNA extraction.

\section{Physicochemical analysis}

The following physicochemical properties were measured: soil water content, $\mathrm{pH}$, electrical conductivity (EC), soil organic content (SOC), available N, Olsen P, and soil bulk density (BD). Soil $\mathrm{pH}$ and EC were measured in soil-water suspensions (1:5 and 1:2.5 soil-water ratio, respectively). The SOC was determined using the Walkley-Black dichromate oxidation method (Diaz-Zorita 1999). Available soil $\mathrm{N}$ was determined with the alkaline hydrolysis diffusion method (Mulvaney and Khan 2001). Available $\mathrm{P}$ was determined using the $0.5 \mathrm{M} \mathrm{NaHCO}_{3}$ method (Page et al. 1982). The $\mathrm{BD}$ of the $0-20 \mathrm{~cm}$ depth was also determined using a soil core $\left(100 \mathrm{~cm}^{3}\right)$.

\section{DNA extraction, PCR amplification, Illumina MiSeq high-throughput sequencing, and sequencing data processing}

The soil microbial DNA was extracted from $0.5 \mathrm{~g}$ soil samples using a FastDNA SPIN Kit for soil (Mo Bio PowerSoil DNA Isolation Kit) according to the manufacturer's instructions. The V3-V4 regions of the bacterial 16S rRNA gene were amplified using PCR (30 cycles of predenaturation at 
$95^{\circ} \mathrm{C}$ for $5 \mathrm{~min} ; 25$ cycles of denaturation at $95^{\circ} \mathrm{C}$ for $30 \mathrm{~s}$, annealing at $56^{\circ} \mathrm{C}$ for $30 \mathrm{~s}$, and extension at $72^{\circ} \mathrm{C}$ for $30 \mathrm{~s}$; with a final extension at $72^{\circ} \mathrm{C}$ for $10 \mathrm{~min}$ ). The primer sets were as follows: $336 \mathrm{~F}$ : 5'-GTACTCCTACGGGAGGCAGCA-3'; 806R: 5'-GTGGACTACHVGGGT WTCTAAT-3'. The PCR reactions were performed in a $50 \mu \mathrm{L}$ mixture containing $1 \mu \mathrm{L}$ of template DNA (30 ng), $2 \mu \mathrm{L}$ of each primer $(10 \mu \mathrm{M}), 4 \mu \mathrm{L}$ of $2.5 \mathrm{mM}$ dNTPs, $5 \mu \mathrm{L}$ of $10 \times$ Pyrobest buffer, $0.3 \mu \mathrm{L}$ of Pyrobest DNA polymerase $\left(2.5 \mathrm{U} / \mu \mathrm{L}\right.$, TaKaRa), and $35.7 \mu \mathrm{L}$ of $\mathrm{ddH}_{2} \mathrm{O}$.

After the PCR process, the DNA amplicons were extracted from $2 \%$ agarose gels and purified using an AxyPrep DNA Gel Extraction Kit (Axygen Biosciences, Union City, CA, USA) according to the manufacturer's instructions and then quantified using QuantiFluor ${ }^{\mathrm{TM}}$-ST (Promega, Madison, WI, USA). Purified amplicons were pooled in equimolar and paired-end sequenced $(2 \times 250)$ on an Illumina MiSeq platform (MajorBio Shanghai Technologies, Shanghai, China) according to standard protocols.

Raw FASTQ files were de-multiplexed and quality-filtered using QIIME (version 1.17) with the following criteria: (i) $250 \mathrm{bp}$ reads were truncated at any site receiving an average nucleotide length $<$ 20 over a 10 bp sliding window and (ii) truncated reads shorter than 50 bp were discarded. Following exact barcode matching, we removed sequences with two nucleotide mismatches in primer matching as well as reads containing ambiguous characters. Only sequences that overlapped in regions longer than $10 \mathrm{bp}$ were assembled according to their overlapping sequence. Finally, the reads that could not be assembled were discarded. To characterize microbial diversity, operational taxonomic units (OTUs) were clustered with a $97 \%$ similarity cutoff using UPARSE. Chimerical sequences were identified and removed using UCHIME (Caporaso et al. 2010; Kunin et al. 2010). The Chaol index $\left(S_{\text {Chaol }}\right)$ (the estimated number of OTUs), which indicates species richness, was calculated using the following equation:

$$
S_{\text {Chao } 1}=S_{o b s}+\frac{n_{1}\left(n_{1}-1\right)}{2\left(n_{2}+1\right)}
$$

where $\mathrm{S}_{o b s}$ is the observed number of OTUs, $n_{l}$ is the number of OTUs with only one sequence, and $n_{2}$ is the number of OTUs with only two sequences (Liu et al. 2014).

The Shannon index $\left(H_{\text {Shannon }}\right)$ (Schloss et al. 2009), which indicates community diversity within the sample (Jurasinski et al. 2009), was determined as follows:

$$
H_{\text {shannon }}=-\sum_{i=1}^{S_{\text {obs }}} \frac{n_{i}}{N} \ln \frac{n_{i}}{N}
$$


where $S_{o b s}$ is the number of observed OTUs, $n_{i}$ is the number of individuals in the OTU, and $N$ is the total number of individuals in the community.

\section{Statistical analyses}

Software R (R Development Core Team, 2008) was used to calculate the percentage of classifiable reads and generate the figures. Analyses of variance (ANOVA) and the least significant range test (Tukey's method) were performed with SPSS 17.0 to test the significance $(p<0.05)$ of the differences among the treatments. The principal component analysis (PCA) and canonical corresponding analysis (CCA) were generated by Canoco 4.5 software.

\section{Results}

\section{Soil physicochemical properties}

Soil $\mathrm{pH}$ and SOC in the $0-20 \mathrm{~cm}$ depth were greatest in the $15-$ and 5-yr fields (Table 1). Reclamation had no significant effect on either soil BD or soil water content $(P>0.05)$. Soil EC was greatest in the abandoned and 1-yr fields. Available $\mathrm{N}\left(69.89 \mathrm{mg} \mathrm{kg}^{-1}\right)$ and available $\mathrm{P}\left(52.06 \mathrm{mg} \mathrm{kg}^{-1}\right)$ were greatest in the 5-yr field.

The abandoned and 1-yr fields were characterized by a high degree of micro-aggregation $(<0.25$ mm fraction), accounting for 69.69 and $36.41 \%$ of the soil mass in those two fields, respectively. The micro-aggregate content decreased as reclamation time increased, reaching $6.14 \%$ of the soil mass in the 10-yr field. The 10- and 5-yr fields had a significantly greater proportion of soil in the large macro-aggregate $(>5$ and 5-2 mm) fractions than any of the other fields $(P<0.05)$. The two size classes combined contained $37.47 \%$ of the soil mass in the $10-\mathrm{yr}$ field and $31.55 \%$ of the soil mass in the 5-yr field $(P<0.05)$. There was no significant difference in the proportion of soil in the small macro-aggregate (2-1 and 1-0.25 mm) fractions among the 1-, 5-, 10-, and 15-yr fields.

\section{Bacterial community composition}

A 16S rRNA gene sequence analysis was performed on 25 soil samples ( 5 samples per field). A total of 1187438 high-quality sequences were obtained from the samples after all of the raw sequences had been subjected to quality control processing ( including trimming and filtering) and the low quality sequences were removed. The effective number of sequences was 1122101 (Table 2). The overall number of OTUs detected by analysis was 51007 , based on $97 \%$ nucleotide sequence 
identity between reads. To assess whether sampling provided sufficient OTU coverage to describe the bacterial composition of each site accurately, individually-based rarefaction curves were generated for each site (Fig. S1). All of the rarefaction curves tended to approach the saturation plateau. This indicated that the data volume of sequenced reads was reasonable and that the discovery of a high number of reads made a small contribution to the total number of OTUs. The rarefaction curves indicated large variation in the total number of OTUs among the different samples. The OTU numbers of the 25 soil samples ranged from 1361 to 2522 , with the $15-\mathrm{yr}$ field having the richest diversity (2 364 OTUs), followed by the 10-yr (2 242 OTUs) and 5-yr (2 210 OTUs) fields. The 1-yr field showed the lowest diversity with only 1464 OTUs.

At the phylum level, the top 11 phyla were selected, and the remaining sequences were assigned to a cluster named "Others" (Fig. 2). The results revealed that Proteobacteria was the most abundant phylum across all 25 soil samples. The proportions of Proteobacteria ranged from $26.00 \%$ in the 10 -yr field to $50.70 \%$ in the $15-y r$ field. The other dominant phyla were Actinobacteria $(3.20 \%-31.50 \%$, averaging $13.87 \%)$, Gemmatimonadetes $(8.20 \%-21.10 \%$, averaging $16.30 \%)$, Acidobacteria $(1.20 \%-$ $33.50 \%$, averaging $12.42 \%)$, Bacteroidetes $(2.80 \%-24.40 \%$, averaging $8.16 \%)$, Chloroflexi $(0.80 \%-$ $12.60 \%$, averaging 5.11\%), and Planctomycetes $(0.20 \%-4.20 \%$, averaging $2.10 \%)$. These seven phyla dominated $(93.27 \%)$ the bacterial communities in all soil samples. The following phyla were present at less than 2\%: Nitrospirae (averaging 1.87\%), and Verrucomicrobia (averaging 1.24\%).

We performed LefSe analyses to examine how taxa differed most in relative abundance among the five fields. The cladogram in Supplementary Fig. S2 shows that many taxa were common among the five fields; however, there were some specific differences. For example, the abandoned field had the highest relative abundances of Chloroflexi and Planctomycetes. The 1-yr field had the highest relative abundances of Actinobacteria, Bacteroidetes, and Firmicutes. The 5-yr field had the greatest relative abundance of Proteobacteria. Finally, the 10-yr field had the highest relative abundance of Acidobacteria, Proteobacteria, and Nitrospirae.

The composition of the bacterial community varied not only among reclamation times, but also among aggregate size classes (Fig. 2). In abandoned farmland, the abundance of the Proteobacteria community was greatest in the $>5 \mathrm{~mm}$ fraction and least in the $1-0.25 \mathrm{~mm}$ fraction. In the $10-\mathrm{yr}$ field, Proteobacteria abundance in the 10-yr field increased as aggregate size decreased; however, in the 1-, 5-, and 15-yr fields the micro-aggregate fraction $(<0.25 \mathrm{~mm})$ had the lowest Proteobacteria 
abundance among the aggregate size classes.

\section{Bacterial community richness and diversity}

The PD, Chao1, and Shannon indices confirmed that reclamation increased soil bacterial diversity, except for the 1-yr field (Table 2). The ANOVA analysis of the PD, Chao1, and Shannon indices also shown significant differences $(P=0.0001)$, and the post-hoc pairwise tests showed that the 15-yr field was significantly different from the other fields. The average Shannon diversity indices were 9.05 in the 15 -yr field, 8.79 in the 10 -yr field, and 8.61 in the 5 -yr field. These results indicated that the Shannon diversity increased with time since reclamation.

The PD, Chao1, and Shannon values tended to be greatest in the 1-0.25 mm fraction (Table 2). The following exceptions should be noted: (i) in the 1-yr soil the PD and Shannon values were greatest in the 2-1 mm fraction, (ii) in the 5-yr soil the Shannon index was greatest in the $<0.25 \mathrm{~mm}$ fraction, and (iii) in the 10-yr soil the 5-2 mm fraction had the highest PD value and the $2-1 \mathrm{~mm}$ fraction had the highest Chao1 value.

The similarity of the soil samples was evaluated according to principal coordinate analysis (PCoA) and cluster analysis (CA). The PCoA was conducted to estimate $\beta$-diversity, which represents the community diversity between samples (Lozupone and Knight 2005) in the Illumina-MiSeq sequencing data based on the UniFrac distance matrix (Peiffer et al. 2013) created by QIIME (Caporaso et al. 2010). The PCoA indicated that $\beta$-diversity changed with time since reclamation (Fig. 3). As shown by the weighted UniFrac analysis, the contributions of the first principal component, the second principal component, and the third principal component were 56.69, 15.78, and 9.05\%, respectively. It is noteworthy that separation existed among the abandoned, 1-yr, 5-yr, 10-yr, and 15yr fields. However, some overlap was observed among samples from the 5-, 10-, and 15-yr fields. This meant that the 5-, 10-, and 15-yr fields had some of the same OTUs but at different levels.

Cluster analysis was conducted to analyze the similarity of the soil samples (Fig. 4). The results showed that the soil samples were clustered into six groups. In the abandoned field, the five aggregate fractions were clustered in two groups, with $>5$ and 5-2 mm aggregates in the same group, and $2-1,1-0.25$ and $<0.25 \mathrm{~mm}$ aggregates in the other group. This result was similar to that obtained by PCoA. In the 1-yr field, the $>5 \mathrm{~mm}$ fraction was slightly separated from the other size fractions. In the 5 -yr field, the $<0.25 \mathrm{~mm}$ aggregates formed a cluster that was separate from the other four size fractions. The 10- and 15-yr fields showed similar patterns, with the five 
aggregate fractions grouped together in one cluster. Overall, the results of cluster analysis were consistent with those of PCoA (Fig. 4). Hierarchical cluster analysis of the similarity of the bacterial communities further confirmed that time since reclamation is the major determinant of bacterial community structure.

The PCA results showed differences in the diversity of the bacterial community among reclamation times (Fig. 5). The PC1 and PC2 accounted for $82.9 \%$ of total variance. All of the bacterial communities at the phylum level were distributed in the four quadrants of the PCA results. For Actinobacteria and Acidobacteria, the only two sources were observed in the second and fourth quadrants, and they had loading scores that were higher on PC1 than those of Bacteroidetes, Firmicutes, TM7, Chloroflexi, Verrucomicrobia, Planctomycetes, Nitrospirae, Gemmatimonadetes and Proteobacteria. Actinobacteria scored highest in PC1, whereas TM7 and Gemmatimonadetes scored highest in PC2. This showed that Actinobacteria and Acidobacteria were the most important bacterial communities in the five fields. The abandoned, 1-, 10-, and 15-yr fields were separated in PC1. The blue circles representing different aggregates classes in the 5-yr field were mainly distributed in the positive direction of PC2 and separate from the other fields. Moreover, the bacterial community structures of aggregate fractions in the 10- and 15-yr fields were clustered in the second principal component axis, whereas the aggregate classes in the 5-yr field were separated from each other. This indicated that 10- and 15-yr fields have more similar bacterial assemblages than those of the other fields.

\section{Environmental factors and bacterial community diversity}

Pearson correlations were calculated to investigate correlations between diversity parameters and environmental factors (Table 3). The results showed that SOC was significantly positively correlated with bacterial richness (OTUs) and with the diversity parameters (Chao1 and PD) $(P<$ 0.05). The other environmental factors, including $\mathrm{pH}, \mathrm{EC}, \mathrm{BD}, \mathrm{EC}$, available $\mathrm{N}$, and available $\mathrm{P}$, were not significantly correlated with bacterial richness or with any of the diversity parameters $(P>0.05)$.

Redundancy analysis (RDA) was performed to investigate the relationship between the bacterial communities and the environmental factors (Fig. 6). The results showed that that $71.40 \%$ of the variation was explained by RDA axis 1 and $22.48 \%$ was explained by RDA axis 2 . The bacterial communities within the five fields were distributed in four quadrants. The RDA analysis revealed that EC, SOC, and available $\mathrm{N}$ were the main environmental factors influencing soil bacterial community 
composition. Additionally, Pearson correlations were calculated between the most abundant bacterial phyla and environmental factors. The relative abundance of Actinobacteria and Bacteroidetes was significantly positively correlated with EC and negatively correlated with SOC and available N $(P<$ 0.05). The relative abundance of Gemmatimonadetes was positively correlated with SOC and soil available P. In addition, the relative abundance of Acidobacteria and Nitrospirae was negatively correlated with soil EC. Soil $\mathrm{pH}$, soil moisture content, and BD showed no correlation with any bacterial phyla.

Two-way ANOVA was performed to better understand the effect of soil aggregate size and reclamation time on the bacterial community (Table S1). The ANOVA showed that time since reclamation $(P=0.001)$ and soil aggregate fractions $(P=0.004)$ were both statistically significant determinants of community composition $(P<0.05$, Table $\mathrm{S} 1)$.

\section{Discussion}

\section{Soil properties}

Soil salinization has become a serious environmental problem worldwide, causing major reductions in arable land, crop productivity, and crop quality (Shahbaz and Ashraf, 2013). China has less than $9 \%$ of the world's arable land with which to feed over $22 \%$ of the global population (Chen 2007). Under the pressure of rapid population growth, more and more abandoned salinized farmland will be reclaimed for use as arable land. Therefore, knowledge about how soil physicochemical properties change after reclamation could be helpful for understanding soil productivity.

Significantly lower soil EC was observed in the 5-, 10-, and 15-yr fields than in the abandoned field. This is consistent with our previous study which showed that soil EC declined as time since reclamation increased (Zhang et al. 2017). The SOC concentrations in the 5-, 10-, and 15-yr fields were significantly greater than those in the abandoned field $(P<0.05)$. Xinjiang is a desert region and biomass production is generally low. Agricultural soils are irrigated using drip irrigation, thus increasing biomass production. Cotton residue was mixed into the soil after harvest in the autumn. Cotton roots are also an important source of organic C. This additional organic matter would change the structural, biological, and chemical properties of the soil. This may explain why SOC increased after the reclamation of the abandoned farmland. Soil available N and $\mathrm{P}$ content significantly increased after reclamation, probably because of fertilization application ( $\mathrm{Zu}$ et al. 2014). The 
proportion of macro-aggregates $(>0.25 \mathrm{~mm})$ increased as the number of reclamation years increased. After $10-\mathrm{yr}$ of cotton production, the $>0.25 \mathrm{~mm}$ aggregates accounted for $93.9 \%$ of total soil mass. This was $67.7 \%$ greater than that in abandoned farmland. The increases in the $>0.25 \mathrm{~mm}$ fraction indicate that the soil structure became more stable after reclamation.

\section{Bacterial community composition and diversity}

Illumina sequencing of bacterial $16 \mathrm{~S}$ rRNA indicated notable shifts in bacterial community structure after the reclamation of abandoned salinized land. The number of OTUs in the 25 samples ranged between 1361 to 2522 OTUs, with an average of 1161 OTUs. The rarefaction curves also tended to plateau, indicating that the library was large enough to reflect the bacterial diversity among the different fields.

The most dominant phylum in all soil samples was related to Proteobacteria, which was consistent with the findings of previous studies (Zhang et al. 2012; Sun et al. 2008; Shi et al. 2014). The other dominant phyla were Actinobacteria (13.87\%), Gemmatimonadetes (16.30\%), Acidobacteria (12.42\%), Bacteroidetes (8.16\%), Chloroflexi (5.11\%), and Planctomycetes (2.10\%). These results suggest that the soil bacterial community in the Manasi River Basin is not unique, despite the rather severe environment. Significant differences in soil bacterial composition were observed among the five reclamation treatments. In particular, the relative abundance of Proteobacteria was high in the 5-yr farmland, whereas Acidobacteria and Gemmatimonadetes had the highest relative abundance in the 10- and 15-yr fields. Our results were consistent with the finding that the relative proportion of Proteobacteria is closely associated with soil available nutrient content (Fierer et al. 2007; Buée et al. 2009). Among the treatments in this study, the 5-yr field had the highest SOC, available N, and available P. This may explain why the 5-year field also had the highest relative abundance of Proteobacteria.

Soil microbial diversity is critical to the integrity, function, and long-term sustainability of soil ecosystems (Kennedy and Smith 1995). Species diversity indices are important measures of microbial community and are determined by a combination of both historical and contemporary effects (Martiny et al. 2006; Sun et al. 2014). Increasingly, research suggests that greater species diversity is associated with greater ecosystem stability (McNaughton 1994); therefore, the maintenance and restoration of microbial biodiversity is becoming a key issue in sustainable agricultural systems (Zhao et al. 2014). In our study, we found that the PD, Chaol, and Shannon indices were lowest in 
abandoned farmland and increased gradually after 1-yr of cotton production. Overall, the PD, Chao1, and Shannon values were highest in the 10 - and 15 -yr fields $(P<0.05)$. This is because relatively little residue was incorporated in the 1-yr field and because SOC, available $\mathrm{N}$, and available $\mathrm{P}$ were significantly less in the 1-yr field than in the other treatments. Hence the increase of soil bacterial abundance and diversity might have contributed to the reclamation of abandoned farmland.

\section{Soil chemical properties, reclamation time, and soil aggregation}

Significant positive correlations were found between SOC and bacterial richness $(\mathrm{r}=0.91, P<$ 0.05), Chaol ( $\mathrm{r}=0.98, P<0.01)$, and PD $(\mathrm{r}=0.89, P<0.05)$. A previous study in Argentina indicated that bacterial richness and diversity were linearly related with SOC (Gomez et al., 2006), which was consistent with our study. The SOC is closely related to nutrient supplying power, and frequently identified as a key indicator of soil quality (Reeves, 1997). Therefore, we can hypothesize that SOC can drive the soil bacterial community. In addition, Spearman correlation and RDA suggested that EC was the second largest explanatory factor (Table 4). This result is consistent with Gao et al. (2015), who used CCA to analyze the relationships between bacterial communities and environmental factors in the $0-20 \mathrm{~cm}$ soil depth in the Yellow River Delta region.

Soil pH was reported as a strong indicator of soil bacterial community composition (Rousk et al. 2010; Liu et al. 2015). However, no correlations were found between soil pH and the most abundant phyla in this study. Our results were inconsistent with previous studies which showed that soil $\mathrm{pH}$ is a better predictor of soil bacterial community structure in alkaline sediment than in soils with other $\mathrm{pH}$ levels (Xiong et al., 2012). This phenomenon may have been caused by variations in soil $\mathrm{pH}$ in this study (ranging from 7.85 to 8.58). In addition, neither soil moisture content nor BD were correlated with abundant phyla (Fig. 7). One possible explanation is moisture content and BD did not change significantly after the reclamation of abandoned farmland (Table 1).

Soil available $\mathrm{N}$ was negatively correlated with Actinobacteria and Bacteroidetes, whereas Gemmatimonadetes was positively correlated with soil available P. Ramirez et al. (2010) observed that the relative abundance of Actinobacteria was positively correlated with soil N. Na et al. (2016) found that Gemmatimonadetes was positively correlated with soil available P. Thus, we hypothesize that soil properties such as soil available $\mathrm{P}$ and available $\mathrm{N}$ can drive bacterial communities in some specific situations. The exact effects of these nutrients depend on land use, cropping system, fertilization, and elevation (Lauber et al. 2008; Shen et al. 2013; Pan et al. 2014). The bacterial 
communities were well grouped according to time since reclamation (Fig. 3, 4, 5). The relationship between soil aggregate fractions and time since reclamation demonstrated that soil bacterial species was associated with those two factors (Table S1, $P<0.05$ ). These results provide a small but important piece of information necessary for better understanding soil microbial diversity in northwest China. The information is important for the reclamation of abandoned salinized farmland.

\section{Conclusions}

The results indicate that reclamation of abandoned farmland for cotton production can increase SOC, available $\mathrm{N}$, available $\mathrm{P}$, and macro-aggregation $(>0.25 \mathrm{~mm})$. High throughput Illumina MiSeq sequencing was used to investigate bacterial community structure. Over 1122101 sequences were analyzed. The result indicated that the most abundant phyla across all 25 soil samples were Proteobacteria, Actinobacteria, Gemmatimonadetes, Acidobacteria, Bacteroidetes, and Chloroflexi. The PD, Chao1, and Shannon indices increased as time since reclamation increased. The PD, Chao1, and Shannon values were generally, but not always, greatest in the $1-0.25 \mathrm{~mm}$ fraction. Soil SOC and EC were the main environmental factors affecting changes in the bacterial communities. Soil aggregate size and time since reclamation significantly affected bacterial species composition and diversity; however, the exact nature of this relationship is uncertain. Longer term, field-based experiments will be needed to evaluate which factors have the most important effect on microbial diversity.

\section{Acknowledgements}

This study was supported by National Natural Science Foundation of China (grant no. 31360320), Special Funds for Scientific Research on Public Causes (201503120), and Xinjiang Production and Construction Crops (2016AD022). The authors gratefully acknowledge the helpful comments from the anonymous referees who helped make significant improvements in the analysis and writing.

\section{Reference}

Buée, M., De Boer, W., Martin, F., Van Overbeek, L., and Jurkevitch, E. 2009. The rhizosphere zoo: an overview of plant-associated communities of microorganisms, including phages, bacteria, archaea, and 
fungi, and of some of their structuring factors. Plant Soil. 321(1): 189-212. doi:10.1007/s11104-0099991-3.

Caporaso, J.G., Kuczynski, J., Stombaugh, J., Bittinger, K., Bushman, F.D., Costello, E.K., Fierer, N., Peña, A.G., Goodrich, J.K., Gordon, J.I., and Huttley, G.A. 2010. QIIME allows analysis of high-throughput community sequencing data. Nature methods. 7(5): 335-336. doi:10.1038/nmeth.f.303.

Chen, J. 2007. Rapid urbanization in China: a real challenge to soil protection and food security. Catena. 69(1): 1-15. doi:10.1016/j.catena.2006.04.019.

Díaz-Zorita, M. 1999. Soil organic carbon recovery by the Walkley-Black method in a typic hapludoll. Comm in Soil Sci Plant Anal. 30(5-6): 739-745. doi:10.1080/00103629909370242.

Dorr de Quadros, P., Zhalnina, K., Davis-Richardson, A., Fagen, J.R., Drew, J., Bayer, C., Camargo, F.A., and Triplett, E.W. 2012. The effect of tillage system and crop rotation on soil microbial diversity and composition in a subtropical acrisol. Diversity. 4(4): 375-395. doi:10.3390/d4040375.

Eynard, A., Schumacher, T.E., Lindstrom, M.J., and Malo, D.D. 2005. Effects of agricultural management systems on soil organic carbon in aggregates of Ustolls and Usterts. Soil Till Res. 81(2): 253-263. doi:10.1016/j.still.2004.09.012.

Fan, H., Pan, X., Li, Y., Chen, F., and Zhang, F. 2008. Evaluation of soil environment after saline soil reclamation of Xinjiang oasis, China. Agronomy J. 100(2): 471-476. doi:10.2134/agronj2007.0100.

Fierer, N., and Jackson, R.B. 2006. The diversity and biogeography of soil bacterial communities. Proceedings of the National Academy of Sciences of the United States of America. 103(3): 626-631. doi: 10.1073/pnas.0507535103. PMID:16407148.

Fierer, N., Bradford, M.A., and Jackson, R.B. 2007. Toward an ecological classification of soil bacteria. Ecology. 88(6): 1354-1364. doi:10.1890/05-1839. PMID:17601128.

Gans, J., Wolinsky, M., and Dunbar, J. 2005. Computational improvements reveal great bacterial diversity and high metal toxicity in soil. Science. 309(5739): 1387-1390. doi:10.1126/science.1112665.

Gao, Y.C., Wang, J.N., Guo, S.H., Hu, Y.L., Li, T.T., Mao, R., and Zeng, D.H. 2015. Effects of salinization and crude oil contamination on soil bacterial community structure in the Yellow River Delta region, China. Appl Soil Ecol. 86: 165-173. doi:10.1016/j.apsoil.2014.10.011.

Gomez, E., Ferreras, L., and Toresani, S. 2006. Soil bacterial functional diversity as influenced by organic amendment application. Bioresour Technol. 97(13): 1484-1489. doi:10.1016/j.biortech.2005.06.021. PMID: 16168637. 
Gong, Z.T., Lei, W.J., and Chen, H.Z. 1988. Chinese dryland soils (in Chinese). Arid Zone Res. 2:1-9

He, J.Z., Shen, J.P., Zhang, L.M., Zhu, Y.G., Zheng, Y.M., Xu, M.G., and Di, H. 2007. Quantitative analyses of the abundance and composition of ammonia-oxidizing bacteria and ammonia-oxidizing archaea of a Chinese upland red soil under long-term fertilization practices. Environ Microbiol. 9(9): 2364-2374. doi: 10.1111/j.1462-2920.2007.01358.x. PMID:17686032.

Jurasinski, G., Retzer, V., and Beierkuhnlein, C. 2009. Inventory, differentiation, and proportional diversity: a consistent terminology for quantifying species diversity. Oecologia. 159(1): 15-26. doi:10.1007/s00442008-1190-z. PMID:18953572.

Kennedy, A.C., and Smith, K.L. 1995. Soil microbial diversity and the sustainability of agricultural soils. In The significance and regulation of soil biodiversity. Springer Netherlands. 75-86. doi:10.1007/978-94-0110479-1.

Kennedy, N., Brodie, E., Connolly, J., and Clipson, N. 2006. Seasonal influences on fungal community structure in unimproved and improved upland grassland soils. Can J Microbiol. 52(7): 689-694. doi:10.1139/w06015. PMID:16917526.

Kunin, V., Engelbrektson, A., Ochma, H., and Hugenholtz, P. 2010. Wrinkles in the rare biosphere: pyrosequencing errors can lead to artificial inflation of diversity estimates. Environ Microbiol. 12(1): 118-123. doi: 10.1111/j.1462-2920.2009.02051.x. PMID:19725865.

Lauber, C.L., Strickland, M.S., Bradford, M.A., and Fierer, N. 2008. The influence of soil properties on the structure of bacterial and fungal communities across land-use types. Soil Biol Biochem. 40(9): 24072415. doi:10.1016/j.soilbio.2008.05.021.

Li, C., Li, X., Kong, W., Wu, Y., and Wang, J. 2010. Effect of monoculture soybean on soil microbial community in the Northeast China. Plant Soil. 330(1-2): 423-433. doi:10.1007/s11104-009-0216-6. PMID:26631020.

Liu, J., Sui, Y., Yu, Z., Shi, Y., Chu, H., Jin, J., Liu, X., and Wang, G. 2014. High throughput sequencing analysis of biogeographical distribution of bacterial communities in the black soils of northeast China. Soil Biol Biochem. 70: 113-122. doi:10.1016/j.soilbio.2013.12.014.

Liu, S., Ren, H., Shen, L., Lou, L., Tian, G., Zheng, P., and Hu, B. 2015. pH levels drive bacterial community structure in sediments of the Qiantang River as determined by 454 pyrosequencing. Front Microbiol. 6. doi: 10.3389/fmicb.2015.00285. PMID:25941515. 
Lozupone, C., and Knight, R. 2005. UniFrac: a new phylogenetic method for comparing microbial communities. Appl Environ Microbiol. 71(12): 8228-8235. doi:10.1128/AEM.71.12.8228-8235.2005. PMID:16332807.

Lupwayi, N.Z., Arshad, M.A., Rice, W.A., and Clayton, G.W. 2001. Bacterial diversity in water-stable aggregates of soils under conventional and zero tillage management. Appl Soil Ecol. 16(3): 251-261. doi:10.1016/S0929-1393(00)00123-2.

Martiny, J.B.H., Bohannan, B.J.M., Brown, J.H., Colwell, R.K., Fuhrman, J.A., Green, J.L., Horner-Devine, M.C., Kane, M., Krumins, J.A., Kuske, C.R., Morin, P.J., Naeem, S., Ovreas, L., Reysenbach, A.L., Smith, V.H., and Staley, J.T. 2006. Microbial biogeography: putting microorganisms on the map. Nat Rev Microbiol 4:102-112. doi:10.1038/nrmicro1341. PMID:16415926.

Matson, P.A., Parton, W.J., Power, A.G., and Swift, M.J. 1997. Agricultural intensification and ecosystem properties. Science. 277(5325): 504-509. doi:10.1126/science.277.5325.504.

McNaughton, S.J. 1994. Biodiversity and function of grazing ecosystems. In Biodiversity and ecosystem function Springer Berlin Heidelberg. 361-383.

Mikha, M.M., and Rice, C.W. 2004. Tillage and manure effects on soil and aggregate-associated carbon and nitrogen. Soil Sci Soc Am J. 68(3): 809-816. doi:10.2136/sssaj2004.8090.

Mulvaney, R.L., and Khan, S.A. 2001. Diffusion methods to determine different forms of nitrogen in soil hydrolysates. Soil Sci Soc Am J. 65(4): 1284-1292. doi:10.2136/sssaj2001.6541284x.

Na, X.F., Zheng, G.Q., Peng, L., Lei, C.Y., Yang, H.Y., Ma, Y., Zhao, Q., and Shi, S.F. 2016. Microbial Biodiversity in Rhizosphere of Lycium bararum L. Relative to Cultivation History. Acta Pedologica Sinica. (1): 241-252. (In Chinese)

Nacke, H., Thürmer, A., Wollherr, A., Will, C., Hodac, L., Herold, N., Schöning, I., Schrumpf, M., and Daniel, R. 2011. Pyrosequencing-based assessment of bacterial community structure along different management types in German forest and grassland soils. PloS one. 6(2): e17000. doi:10.1371/journal.pone.0017000. PMID:21359220.

Nakatsu, C.H. 2007. Soil microbial community analysis using denaturing gradient gel electrophoresis. Soil Sci Soc of Am J 71(2): 562. doi:10.2136/sssaj2006.0080.

O'Donnell, A.G., Young, I.M., Rushton, S.P., Shirley, M.D., and Crawford, J.W. 2007. Visualization, modeling and prediction in soil microbiology. Nat Rev Microbiol. 5(9): 689-699. doi:10.1038/nrmicro1714. 
Page, A.L. 1982. Methods of soil analysis. Part 2. Chemical and microbiological properties. American Society of Agronomy, Soil Science Society of America, Madison, Wisconsin 1159.

Pan, Y., Cassman, N., Hollander, M., Mendes, L.W., Korevaar, H., Geerts, R.H., Veen, J.A., and Kuramae, E.E. 2014. Impact of long-term N, P, K, and NPK fertilization on the composition and potential functions of the bacterial community in grassland soil. FEMS Microbiol Ecol. 90(1): 195-205. doi:10.1111/15746941.12384. PMID:25046442.

Peiffer, J.A., Spor, A., Koren, O., Jin, Z., Tringe, S.G., Dangl, J.L., Buckler, E.S., and Ley, R.E. 2013. Diversity and heritability of the maize rhizosphere microbiome under field conditions. P Natl Acad Sci USA. 110(16): 6548-6553. doi:10.1073/pnas.1302837110. PMID:23576752.

Ramirez, K.S., Lauber, C.L., Knight, R., Bradford, M.A., and Fierer, N. 2010. Consistent effects of nitrogen fertilization on soil bacterial communities in contrasting systems. Ecology. 91(12): 3463-3470. doi: 10.1890/10-0426.1. PMID:21302816.

Rashid, M.I., Mujawar, L.H., Shahzad, T., Almeelbi, T., Ismail, I.M., and Oves, M. 2016. Bacteria and fungi can contribute to nutrients bioavailability and aggregate formation in degraded soils. Microbiol Res. 183: 2641. doi:10.1016/j.micres.2015.11.007. PMID:26805616.

Reeves, D.W. 1997. The role of soil organic matter in maintaining soil quality in continuous cropping systems. Soil Till Res. 43(1-2): 131-167. doi:10.1016/S0167-1987(97)00038-X.

Rousk, J., Bååth, E., Brookes, P.C., Laube, C.L., Lozupone, C., Caporaso, J.G., Knight, R., and Fierer, N. 2010. Soil bacterial and fungal communities across a pH gradient in an arable soil. ISME J. 4(10): 1340-1351. doi:1751-7362/10. PMID:20445636.

Schloss, P.D., Westcott, S.L., Ryabin, T., Hall, J.R., Hartmann, M., Hollister, E.B., Lesniewski, R.A., Oakley, B.B., Parks, D.H., Robinson, C.J. and Sahl, J.W. 2009. Introducing mothur: open-source, platformindependent, community-supported software for describing and comparing microbial communities. Appl Environ Microbiol. 75(23): 7537-7541. doi:10.1128/AEM.01541-09. PMID:19801464.

Schutter, M.E., and Dick, R.P. 2002. Microbial community profiles and activities among aggregates of winter fallow and cover-cropped soil. Soil Sci Soc Am J. 66(1): 142-153. doi:10.2136/sssaj2002.1420.

Schutter, M., Sandeno, J., and Dick, R. 2001. Seasonal, soil type, and alternative management influences on microbial communities of vegetable cropping systems. Biol Fert Soils. 34(6): 397-410. doi:10.1007/s00374-001-0423-7. 
Shen, C., Xiong, J., Zhang, H., Feng, Y., Lin, X., Li, X., Liang, W., and Chu, H. 2013. Soil pH drives the spatial distribution of bacterial communities along elevation on Changbai Mountain. Soil Biol Biochem. 57: 204-211. doi:10.1016/j.soilbio.2012.07.013.

Shahbaz, M., and Ashraf, M. 2013. Improving salinity tolerance in cereals. Critical reviews in plant sciences. 32(4): 237-249. doi:10.1080/07352689.2013.758544.

Shi, Y., Yang, H., Zhang, T., Sun, J., and Lou, K. 2014. Illumina-based analysis of endophytic bacterial diversity and space-time dynamics in sugar beet on the north slope of Tianshan Mountain. Appl Microbiol Biot. 98(14): 6375-6385. doi:10.1007/s00253-014-5720-9. PMID:24752839.

Six, J., Bossuyt, H., Degryze, S., and Denef, K. 2004. A history of research on the link between (micro) aggregates, soil biota, and soil organic matter dynamics. Soil Till Res. 79(1): 7-31. doi:10.1016/j.still.2004.03.008.

Soman, C., Li, D., Wander, M.M., Kent, A.D. 2016. Long-term fertilizer and crop-rotation treatments differentially affect soil bacterial community structure. Plant Soil. 1-15. doi:10.1007/s11104-016-3083-y.

Steenwerth, K.L., Jackson, L.E., Calderón, F.J., Stromberg, M.R., and Scow, K.M. 2002. Soil microbial community composition and land use history in cultivated and grassland ecosystems of coastal California. Soil Biol Biochem 34(11): 1599-1611. doi:10.1016/S0038-0717(02)00144-X.

Sun, B., Wang, F., Jiang, Y., Li, Y., Dong, Z., Li, Z., and Zhang, X.X. 2014. A long-term field experiment of soil transplantation demonstrating the role of contemporary geographic separation in shaping soil microbial community structure. Ecol Evol 4(7): 1073-1087. doi:10.1002/ece3.1006. PMID:24772284.

Sun, L., Qiu, F., Zhang, X., Dai, X., Dong, X., and Song, W. 2008. Endophytic bacterial diversity in rice (Oryza sativa L.) roots estimated by $16 \mathrm{~S}$ rDNA sequence analysis. Microb Ecol. 55(3): 415-424. doi:10.1007/s00248-007-9287-1. PMID:17690836.

Tian, J., Lou, Y., Gao, Y., Fang, H., Liu, S., Xu, M., Blagodatskaya, E., and Kuzyakov, Y. 2017. Response of soil organic matter fractions and composition of microbial community to long-term organic and mineral fertilization. Biol Fert Soils. 1-10. doi:10.1007/s00374-017-1189-x.

Torsvik, V., and Øvreås, L. 2002. Microbial diversity and function in soil: from genes to ecosystems. Curr Opin Microbiol 5(3): 240-245. doi: 10.1016/S1369-5274(02)00324-7. PMID:12057676.

Trivedi, P., Rochester, I.J., Trivedi, C., Van, Nostrand. J.D., Zhou, J., Karunaratne, S., Anderson, I.C., and Singh, B.K. 2015. Soil aggregate size mediates the impacts of cropping regimes on soil carbon and microbial communities. Soil Biol Biochem. 91: 169-181. doi:10.1016/j.soilbio.2015.08.034. 
Wei, K., Chen, Z.H., Zhang, X.P., Liang, W.J., and Chen, L.J. 2014. Tillage effects on phosphorus composition and phosphatase activities in soil aggregates. Geoderma, 217: 37-44. doi:10.1016/j.geoderma.2013.11.002.

Xiong, J.B., Liu, Y.Q., Lin, X.G., Zhang, H.Y., Zeng, J., and Hou, J.Z. 2012. Geographic distance and pH drive bacterial distribution in alkaline lake sediments across Tibetan Plateau. Environ Microbiol. 14: 24572466. doi:10.1111/j.1462-2920.2012.02799.x. PMID:22676420.

Zhang, F.H., Yang, H.C., Gale, W.J., Cheng, Z.B., and Yan, J.H. 2017. Temporal changes in soil organic carbon and aggregate-associated organic carbon after reclamation of abandoned, salinized farmland. J Agri Sci 155(2): 205-215. doi:10.1017/S002185961600023X.

Zhang, T., Shao, M.F., and Ye, L. 2012. 454 Pyrosequencing reveals bacterial diversity of activated sludge from 14 sewage treatment plants. ISME J. 6(6): 1137-1147. doi:10.1038/ismej.2011.188. PMID:22170428.

Zhao, J., Zhang, R., Xue, C., Xun, W., Sun, L., Xu, Y., and Shen, Q. 2014. Pyrosequencing reveals contrasting soil bacterial diversity and community structure of two main winter wheat cropping systems in China. Microb Ecol. 67(2): 443-453. doi:10.1007/s00248-013-0322-0. PMID:24276539.

Zu, C., Li, Z., Yang, J., Yu, H., Sun, Y., Tang, H., Yost, R., and Wu, H. 2014. Acid soil is associated with reduced yield, root growth and nutrient uptake in black pepper (Piper nigrum L.). Agri Sci. 2014. doi:10.4236/as.2014.55047.

\section{Figure legends}

Fig. 1. Sketch map of the Manasi River Basin and the study region.

Fig. 2. Relative abundances of bacterial phyla $(>1 \%)$ in the soil samples. Phyla accounting for less than $1 \%$ of all sequences were grouped in the category "other".

Fig. 3. Principal coordinate analysis (PCoA) scores plot of beta diversity of unweighted UniFrac pairwise distances. The percentages of variation explained by PC1, PC2 and PC3 are indicated in the axis. A, B, C, D and E stand for abandoned, 1-, 5-, 10-, and 15-yr fields, respectively. 1, 2, 3, 4, and 5 represent different aggregates fractions (i.e. $>5,5-2,2-1,1-0.25$, and $<0.25 \mathrm{~mm}$ ).

Fig. 4. Cluster analysis that contain the essential 16S rDNA of soil bacteria under different years of reclamation farmlands. A, B, C, D and E stand for abandoned, 1-, 5-, 10-, and 15-yr fields, respectively. 1, 2, 3, 4, and 5 represent different aggregates fractions (i.e. $>5,5-2,2-1,1-0.25$, and $<0.25 \mathrm{~mm}$ ). 
Fig. 5. Principle component analyses (PCA) with similarity instrumental variable were carried out with 25 soil samples from the study areas. A, B, C, D and E stand for abandoned, 1-, 5-, 10-, and 15-yr fields, respectively. 1, 2, 3, 4, and 5 represent different aggregates fractions (i.e. $>5,5-2,2-1,1-0.25$, and $<0.25 \mathrm{~mm}$ ).

Fig. 6. Cross analysis of bacterial community and soil physicochemical characteristics using redundancy analysis (Canoco 4.5).

Fig. S1. Rarefaction curves of each soil sample at the $3 \%$ cutoff level of. A, B, C, D and E stand for abandoned, 1-, 5-, 10-, and 15-yr fields, respectively. 1, 2, 3, 4, and 5 represent different aggregates fractions (i.e. $>5,5-2,2-1,1-0.25$, and $<0.25 \mathrm{~mm}$ ).

Fig. S2. Cladogram indicating the phylogenetic distribution of bacterial lineages as affected by time since reclamation; the threshold on the logarithmic LDA score for discriminative features was 4.0. Differences are represented in the color of the most abundant taxa (red indicating taxa in the abandoned field, green in the 1-yr field; dark blue in the 5-yr field; purple in the 10-yr field; light blue in the 15-yr field; and yellow is non-significant). Each circle's diameter is proportional to the given taxon's relative abundance. Circles represent phylogenetic levels from domain to genus from the inside outwards. 
Table 1. Selected physical and chemical properties of the soil after abandoned salinized farmland was reclaimed for cotton production.

\begin{tabular}{|c|c|c|c|c|c|c|c|c|c|c|c|c|}
\hline \multirow[b]{2}{*}{ Treatments } & \multirow[b]{2}{*}{$\mathrm{pH}$} & \multirow{2}{*}{$\begin{array}{c}\text { Moisture } \\
\text { content } \\
(\%)\end{array}$} & \multirow{2}{*}{$\begin{array}{c}\text { Bulk } \\
\text { density } \\
\left(\mathrm{g} \cdot \mathrm{cm}^{-3}\right) \\
\end{array}$} & \multirow{2}{*}{$\begin{array}{c}\text { Electric } \\
\text { conductivity } \\
\left(\mathrm{ms} \cdot \mathrm{cm}^{-1}\right)\end{array}$} & \multirow{2}{*}{$\begin{array}{c}\mathrm{SOC} \\
\left(\mathrm{g} \mathrm{kg}^{-1}\right) \\
\end{array}$} & \multirow{2}{*}{$\begin{array}{l}\text { Available } \\
\mathrm{N} \\
\left(\mathrm{mg} \cdot \mathrm{kg}^{-1}\right)\end{array}$} & \multirow{2}{*}{$\begin{array}{c}\text { Olsen } \\
\mathrm{P} \\
\left(\mathrm{mg} \cdot \mathrm{kg}^{-1}\right) \\
\end{array}$} & \multicolumn{5}{|c|}{ Aggregate size distribution (\%) } \\
\hline & & & & & & & & $>5 \mathrm{~mm}$ & $5-2 \mathrm{~mm}$ & $2-1 \mathrm{~mm}$ & $1-0.25 \mathrm{~mm}$ & $\begin{array}{c}<0.25 \\
\mathrm{~mm}\end{array}$ \\
\hline Abandoned & $7.96 \mathrm{bc}^{*}$ & $0.16 \mathrm{a}$ & $1.77 \mathrm{a}$ & $2.77 \mathrm{a}$ & $10.08 \mathrm{bc}$ & $44.26 \mathrm{~d}$ & $12.15 \mathrm{~d}$ & $6.49 \mathrm{~d}$ & $4.00 \mathrm{c}$ & $8.26 \mathrm{~b}$ & $11.57 \mathrm{a}$ & $69.69 \mathrm{a}$ \\
\hline 1 year & $8.02 \mathrm{~b}$ & $0.14 \mathrm{a}$ & $1.72 \mathrm{a}$ & $2.12 \mathrm{a}$ & $8.63 \mathrm{c}$ & $37.11 \mathrm{e}$ & $15.12 \mathrm{~d}$ & $13.61 \mathrm{~cd}$ & $12.26 \mathrm{~d}$ & $21.08 \mathrm{a}$ & $16.63 \mathrm{a}$ & $36.41 \mathrm{~b}$ \\
\hline 5 years & $8.20 \mathrm{ab}$ & $0.13 \mathrm{a}$ & $1.63 \mathrm{a}$ & $0.39 \mathrm{~b}$ & $17.20 \mathrm{a}$ & $69.89 \mathrm{a}$ & $52.06 \mathrm{a}$ & $21.05 \mathrm{bc}$ & $31.55 \mathrm{a}$ & $23.01 \mathrm{a}$ & $15.69 \mathrm{a}$ & $8.70 \mathrm{c}$ \\
\hline 15 years & $8.58 \mathrm{a}$ & $0.15 \mathrm{a}$ & $1.82 \mathrm{a}$ & $0.34 \mathrm{~b}$ & $20.59 \mathrm{a}$ & $52.88 \mathrm{c}$ & $46.65 \mathrm{~b}$ & $32.12 \mathrm{ab}$ & $21.42 \mathrm{~b}$ & $23.36 \mathrm{a}$ & $12.29 \mathrm{a}$ & $10.82 \mathrm{c}$ \\
\hline
\end{tabular}

* Different lowercase letters within a column indicate significant differences $(P<0.05)$. 
Table 2. MiSeq sequencing results and diversity estimates for each sampling site.

\begin{tabular}{|c|c|c|c|c|c|c|c|}
\hline \multirow{2}{*}{ Treatments } & \multirow{2}{*}{$\begin{array}{l}\text { Aggregate } \\
\text { size }(\mathrm{mm})\end{array}$} & \multicolumn{3}{|c|}{ Sequencing results } & \multicolumn{3}{|c|}{ Diversity estimates } \\
\hline & & Raw tags & Clean tags & Total OTUs & PD & Chaol & Shannon \\
\hline \multirow{6}{*}{ Abandoned } & $>5$ & 33626 & 31288 & 1595 & $99.88 \pm 1.70$ & $1973.71 \pm 25.76$ & $8.44 \pm 0.01$ \\
\hline & $5-2$ & 52335 & 44013 & 1842 & $107.39 \pm 1.40$ & $2221.96 \pm 43.19$ & $8.43 \pm 0.00$ \\
\hline & $2-1$ & 45834 & 42680 & 2055 & $122.21 \pm 1.41$ & $2503.26 \pm 28.36$ & $8.80 \pm 0.00$ \\
\hline & $1-0.25$ & 56445 & 53098 & 2207 & $128.67 \pm 1.38$ & $2661.70 \pm 11.04$ & $8.88 \pm 0.01$ \\
\hline & $<0.25$ & 38108 & 37062 & 1908 & $108.27 \pm 2.29$ & $2346.91 \pm 39.55$ & $8.53 \pm 0.01$ \\
\hline & Mean value & 45270 & 41628 & 1921 & 113.28 & 2341.51 & 8.62 \\
\hline \multirow{5}{*}{1 year } & $>5$ & 49442 & 48265 & 1495 & $89.45 \pm 0.86$ & $1878.03 \pm 12.89$ & $7.84 \pm 0.00$ \\
\hline & $5-2$ & 33876 & 32524 & 1361 & $82.19 \pm 1.24$ & $1637.56 \pm 25.36$ & $8.02 \pm 0.00$ \\
\hline & $2-1$ & 36784 & 35272 & 1524 & $91.41 \pm 1.39$ & $1771.70 \pm 1.73$ & $8.18 \pm 0.00$ \\
\hline & $1-0.25$ & 51589 & 49843 & 1511 & $86.66 \pm 0.91$ & $1818.72 \pm 3.69$ & $7.84 \pm 0.00$ \\
\hline & $<0.25$ & 63298 & 60885 & 1429 & $81.27 \pm 0.94$ & $1772.74 \pm 2.23$ & $7.54 \pm 0.00$ \\
\hline \multirow{7}{*}{5 years } & Mean value & 46998 & 45358 & 1464 & 86.19 & 1775.75 & 7.89 \\
\hline & $>5$ & 59124 & 56614 & 2094 & $117.79 \pm 1.46$ & $2700.45 \pm 21.64$ & $7.95 \pm 0.00$ \\
\hline & $5-2$ & 59065 & 46698 & 1946 & $105.79 \pm 1.57$ & $2479.99 \pm 38.75$ & $7.96 \pm 0.00$ \\
\hline & $2-1$ & 44622 & 43283 & 2170 & $118.15 \pm 2.13$ & $2759.13 \pm 49.66$ & $8.32 \pm 0.00$ \\
\hline & $1-0.25$ & 65371 & 63287 & 2448 & $133.01 \pm 0.96$ & $3046.03 \pm 37.27$ & $8.50 \pm 0.0 \mathrm{C}$ \\
\hline & $<0.25$ & 51958 & 49980 & 2391 & $130.76 \pm 2.08$ & $2946.72 \pm 40.69$ & $8.61 \pm 0.00$ \\
\hline & Mean value & 56028 & 51972 & 2210 & 121.10 & 2786.46 & 8.27 \\
\hline \multirow{5}{*}{10 years } & $>5$ & 47375 & 46119 & 2011 & $116.59 \pm 1.73$ & $2518.36 \pm 25.06$ & $8.34 \pm 0.00$ \\
\hline & $5-2$ & 49204 & 48002 & 2351 & $131.63 \pm 1.75$ & $2796.63 \pm 19.89$ & $8.64 \pm 0.00$ \\
\hline & $2-1$ & 39768 & 38843 & 2293 & $127.78 \pm 2.86$ & $2847.93 \pm 48.66$ & $8.74 \pm 0.01$ \\
\hline & $1-0.25$ & 35192 & 33904 & 2273 & $125.44 \pm 2.18$ & $2745.51 \pm 28.82$ & $8.97 \pm 0.01$ \\
\hline & $<0.25$ & 47784 & 40580 & 2283 & $125.66 \pm 1.93$ & $2805.71 \pm 26.27$ & $8.79 \pm 0.01$ \\
\hline \multirow{7}{*}{15 years } & Mean value & 43865 & 41490 & 2242 & 125.42 & 2742.83 & 8.70 \\
\hline & $>5$ & 54031 & 52064 & 2274 & $134.88 \pm 1.55$ & $2785.42 \pm 33.48$ & $8.72 \pm 0.00$ \\
\hline & $5-2$ & 41253 & 40286 & 2298 & $131.88 \pm 2.25$ & $2866.18 \pm 31.71$ & $8.86 \pm 0.01$ \\
\hline & $2-1$ & 46179 & 44854 & 2399 & $137.46 \pm 1.86$ & $2945.63 \pm 35.39$ & $8.97 \pm 0.00$ \\
\hline & $1-0.25$ & 46914 & 45379 & 2522 & $143.41 \pm 1.98$ & $3137.16 \pm 42.47$ & $9.11 \pm 0.00$ \\
\hline & $<0.25$ & 38261 & 37278 & 2327 & $131.26 \pm 2.15$ & $2869.14 \pm 54.72$ & $9.05 \pm 0.00$ \\
\hline & Mean value & 45328 & 43972 & 2364 & 135.78 & 2920.71 & 8.94 \\
\hline
\end{tabular}


Table 3. Correlations between diversity parameters and environmental factors.

\begin{tabular}{ccccc}
\hline Factor & OTUs & Chaol & Shannon & PD \\
\hline $\mathrm{pH}$ & 0.45 & 0.47 & 0.37 & 0.49 \\
$\mathrm{MC}$ & -0.21 & -0.23 & 0.20 & -0.08 \\
$\mathrm{BD}$ & 0.09 & 0.04 & 0.60 & 0.24 \\
$\mathrm{EC}$ & -0.78 & -0.79 & -0.39 & -0.70 \\
SOC & $0.91 *$ & $0.92^{* *}$ & 0.65 & $0.89 *$ \\
$\mathrm{AN}$ & 0.78 & 0.81 & 0.30 & 0.67 \\
$\mathrm{AP}$ & 0.70 & 0.74 & 0.26 & 0.63 \\
\hline
\end{tabular}

Note: OTUs, operational taxonomic units; PD, Faith's phylogenetic diversity; Shannon, nonparametric Shannon diversity index; MC, soil moisture content; BD, soil bulk density; EC, electrical conductivity, SOC, soil organic carbon; AN, available nitrogen; AP, available phosphorus. Pearson correlation coefficients were calculated. ${ }^{*}, P<0.05 ;{ }^{*}, P<0.01$. 
Table 4. Spearman's rank correlations (r) between the 11 most abundant phyla (Relative abundance $>1 \%$ in all samples combined) and selected soil properties.

\begin{tabular}{cccccccc}
\hline & $\mathrm{pH}$ & $\mathrm{MC}$ & $\mathrm{BD}$ & $\mathrm{EC}$ & $\mathrm{SOC}$ & $\mathrm{AN}$ & $\mathrm{AP}$ \\
\hline Proteobacteria & -0.04 & 0.20 & -0.67 & 0.19 & -0.18 & 0.27 & 0.27 \\
Gemmatimonadetes & 0.63 & -0.44 & -0.18 & $\mathbf{- 0 . 9 6}$ & $\mathbf{0 . 9 5}$ & 0.77 & $\mathbf{0 . 9 2}$ \\
Actinobacteria & -0.36 & 0.38 & 0.00 & $\mathbf{0 . 8 4}$ & $\mathbf{- 0 . 9 0}$ & $\mathbf{- 0 . 8 3}$ & -0.68 \\
Acidobacteria & 0.14 & -0.67 & 0.02 & $\mathbf{- 0 . 8 5}$ & 0.75 & 0.67 & 0.43 \\
Bacteroidetes & -0.34 & 0.37 & 0.02 & $\mathbf{0 . 8 2}$ & $\mathbf{- 0 . 8 8}$ & $\mathbf{- 0 . 8 4}$ & -0.67 \\
Chloroflexi & 0.13 & 0.50 & 0.70 & 0.17 & 0.19 & -0.06 & -0.13 \\
Planctomycetes & 0.24 & 0.57 & 0.76 & 0.16 & 0.23 & -0.10 & -0.08 \\
Firmicutes & -0.23 & 0.06 & -0.09 & 0.50 & -0.69 & -0.71 & -0.49 \\
Nitrospirae & 0.07 & -0.75 & -0.01 & $\mathbf{- 0 . 8 3}$ & 0.68 & 0.60 & 0.35 \\
Verrucomicrobia & -0.13 & 0.52 & 0.64 & 0.40 & -0.09 & -0.21 & -0.39 \\
TM7 & -0.52 & 0.19 & 0.49 & 0.45 & -0.33 & -0.29 & -0.69 \\
\hline
\end{tabular}

Note: $\mathrm{MC}$, soil moisture content; $\mathrm{BD}$, soil bulk density; EC, electrical conductivity, SOC, soil organic carbon; AN, available nitrogen; AP, available phosphorus.

Values in bold are significant $(P<0.05)$. 


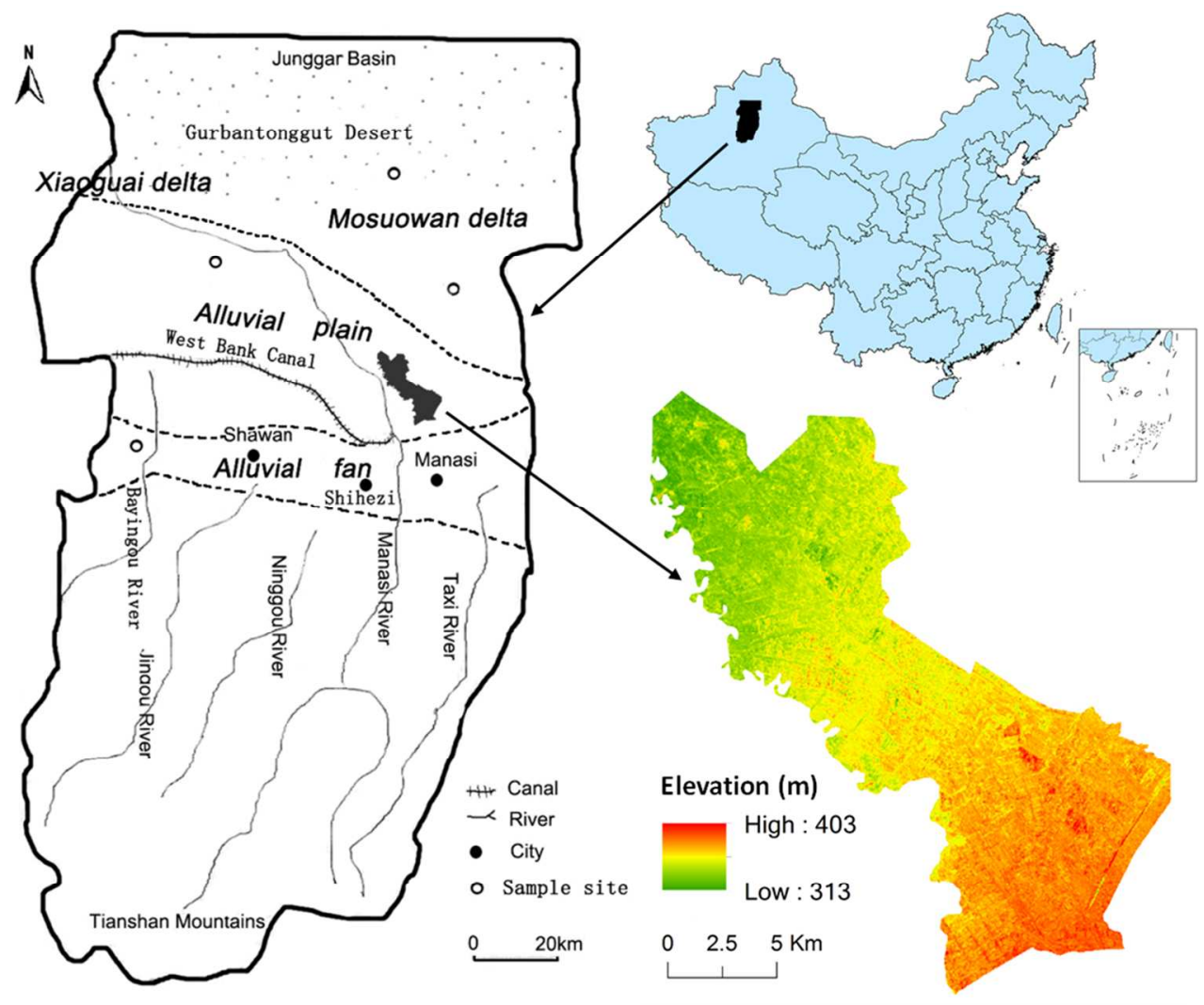

Fig. 1. Sketch map of the Manasi River Basin and the study region. 


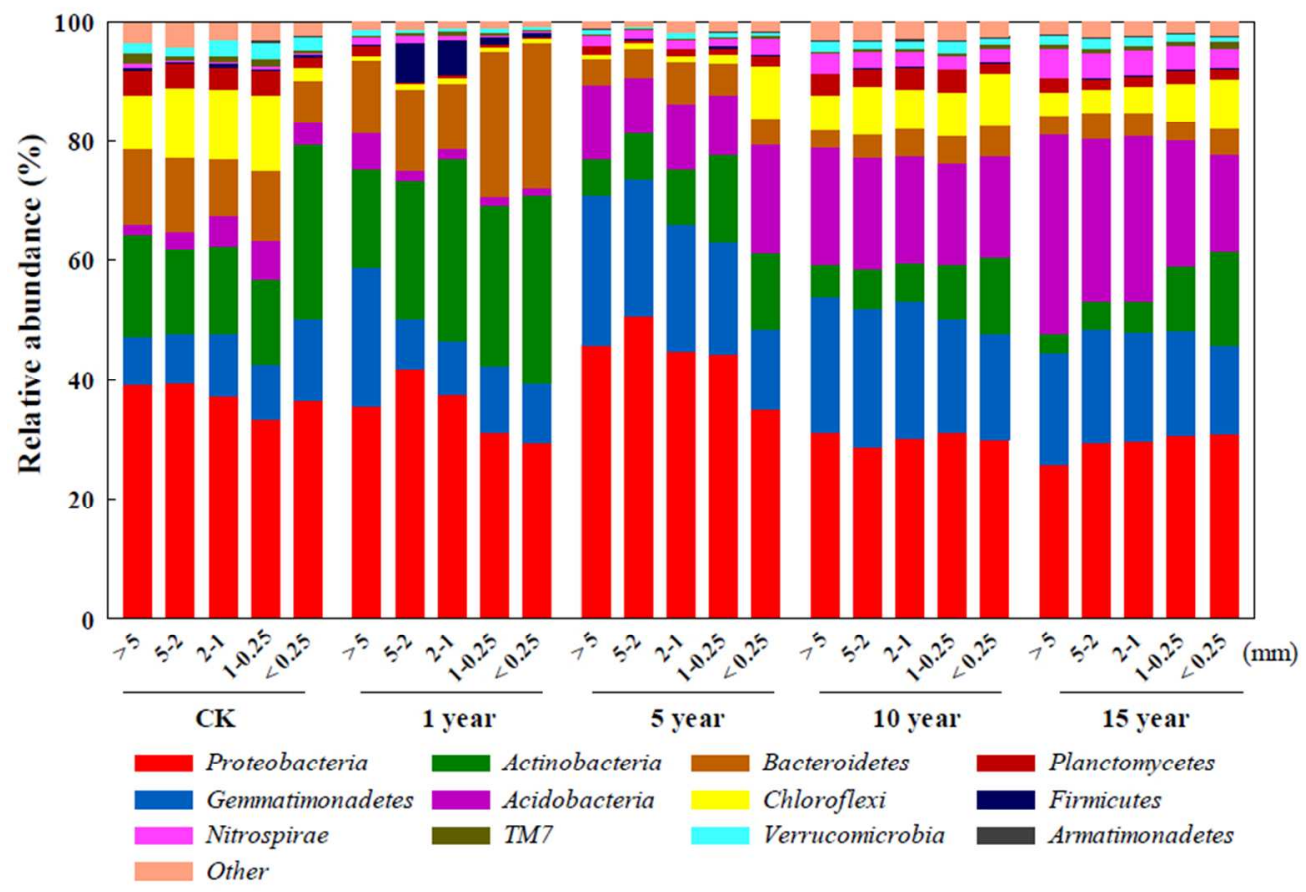

Relative abundances of bacterial phyla ( $>1 \%$ ) in the soil samples. Phyla accounting for less than $1 \%$ of all sequences were grouped in the category "other". 


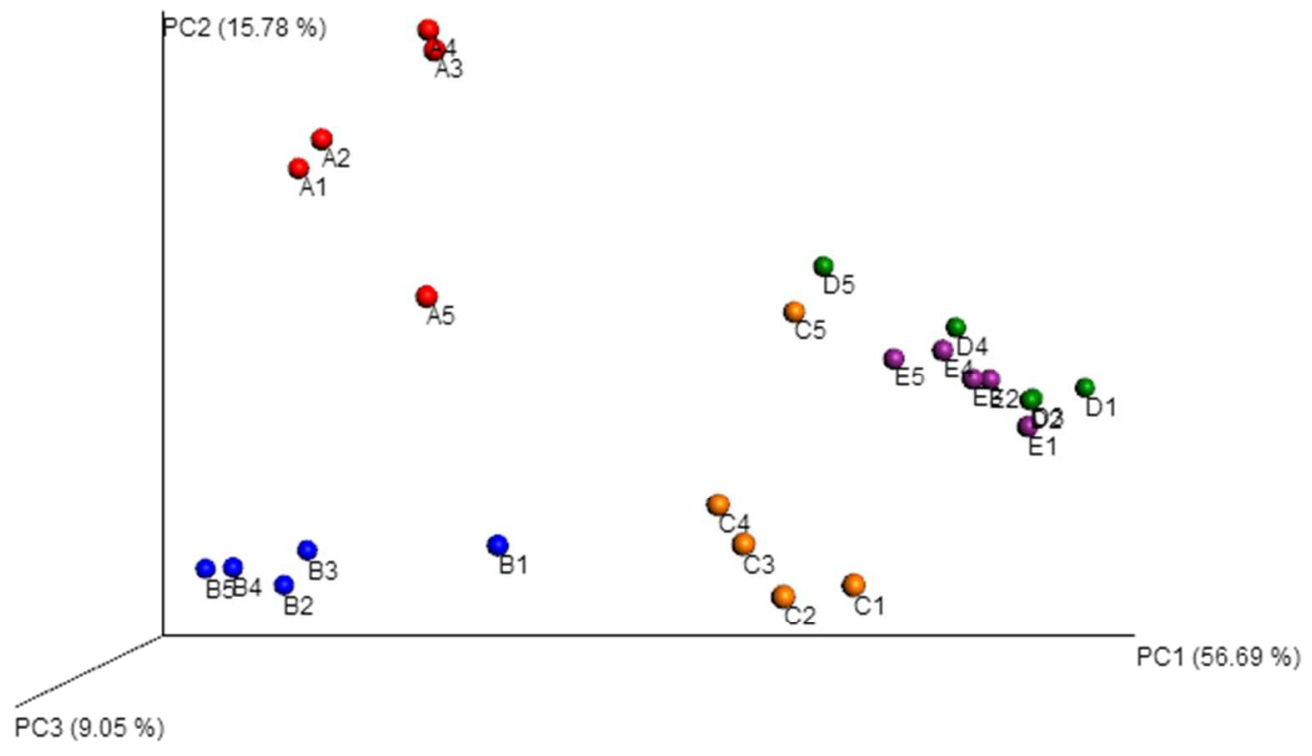

Fig. 3. Principal coordinate analysis (PCOA) scores plot of beta diversity of unweighted UniFrac pairwise distances. The percentages of variation explained by PC1, PC2 and PC3 are indicated in the axis. A, B, C, D and $\mathrm{E}$ stand for abandoned, 1-, 5-, 10-, and 15-yr fields, respectively. 1, 2, 3, 4, and 5 represent different aggregates fractions (i.e. $>5,5-2,2-1,1-0.25$, and $<0.25 \mathrm{~mm}$ ). 


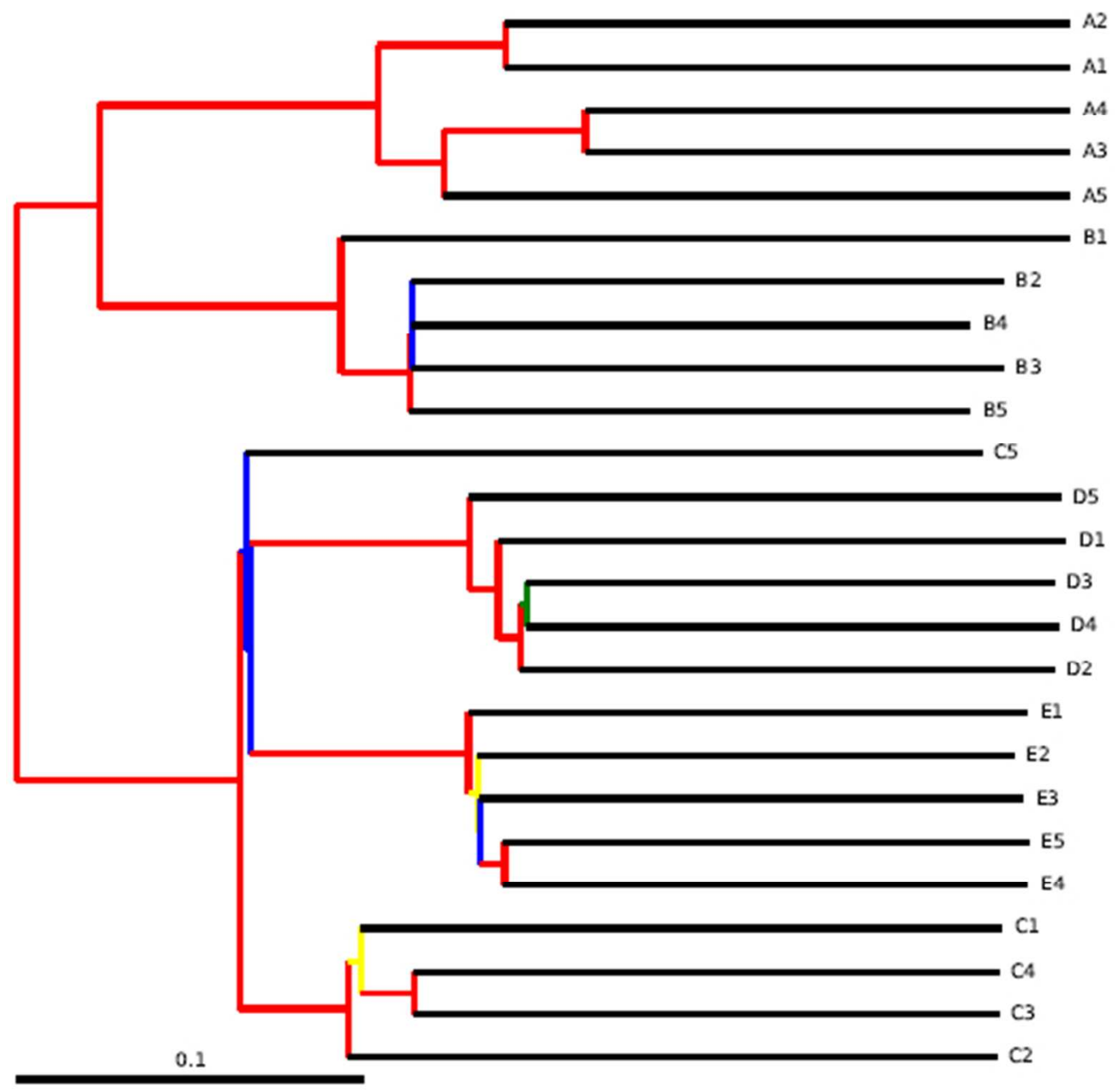

Fig. 4. Cluster analysis that contain the essential 16S rDNA of soil bacteria under different years of reclamation farmlands. A, B, C, D and E stand for abandoned, 1-, 5-, 10-, and 15-yr fields, respectively. 1, $2,3,4$, and 5 represent different aggregates fractions (i.e. $>5,5-2,2-1,1-0.25$, and $<0.25 \mathrm{~mm}$ ). 


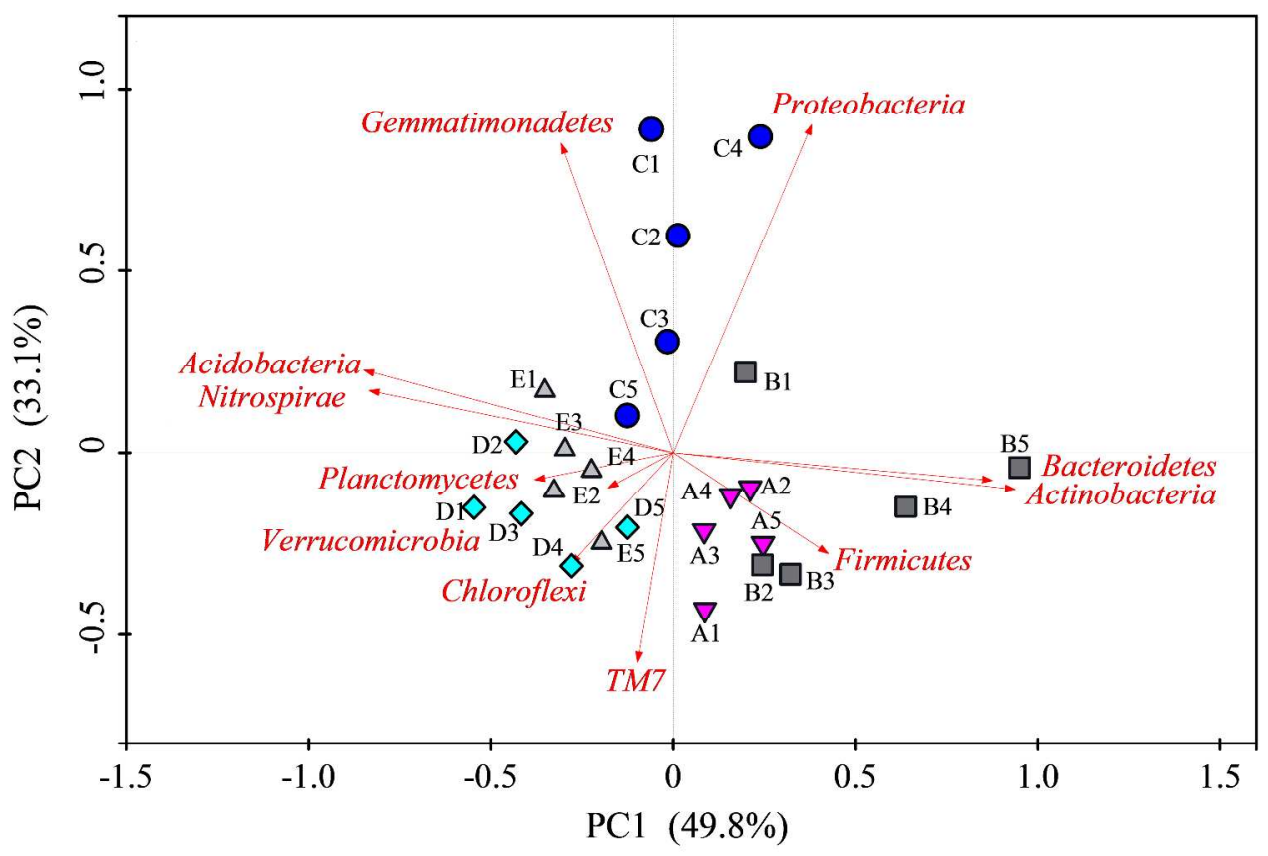

Fig. 5. Principle component analyses (PCA) with similarity instrumental variable were carried out with 25 soil samples from the study areas. A, B, C, D and E stand for abandoned, 1-, 5-, 10-, and 15-yr fields, respectively. $1,2,3,4$, and 5 represent different aggregates fractions (i.e. $>5,5-2,2-1,1-0.25$, and < $0.25 \mathrm{~mm}$ ). 


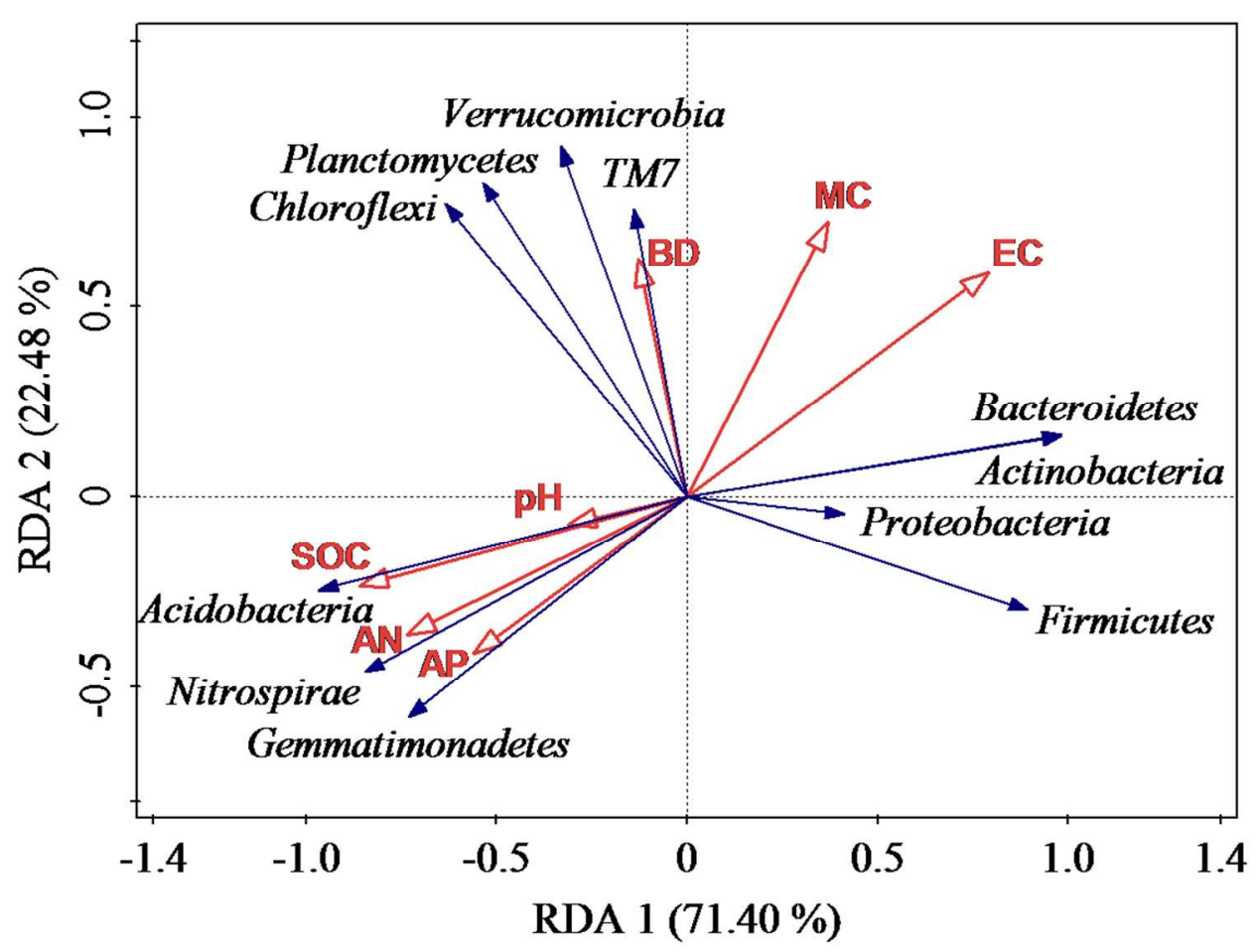

Environmental factors Species

$\rightarrow$

Fig. 6. Cross analysis of bacterial community and soil physicochemical characteristics using redundancy analysis (Canoco 4.5). 
Table S1. Two-way analysis of variance (ANOVA) of reclamation years (Y) and aggregate size (A) on soil bacterial communities (B).

\begin{tabular}{llllll}
\hline Source of variation & Sum of squares & df & Mean square & F value & P value \\
\hline Reclamation Years (Y) & 1.69 & 4 & 0.42 & 0.060 & 0.9933 \\
Aggregates (A) & 0.06 & 4 & 0.02 & 0.002 & 0.9999 \\
Bacteria (B) & 27326.08 & 10 & 2732.61 & 386.185 & 0.0001 \\
$\mathrm{Y} \times \mathrm{A}$ & 0.24 & 16 & 0.015 & 0.002 & 0.9999 \\
$\mathrm{Y} \times \mathrm{B}$ & 5233.20 & 40 & 130.83 & 18.490 & 0.0001 \\
$\mathrm{~A} \times \mathrm{B}$ & 614.65 & 40 & 15.37 & 2.172 & 0.0004 \\
\hline
\end{tabular}




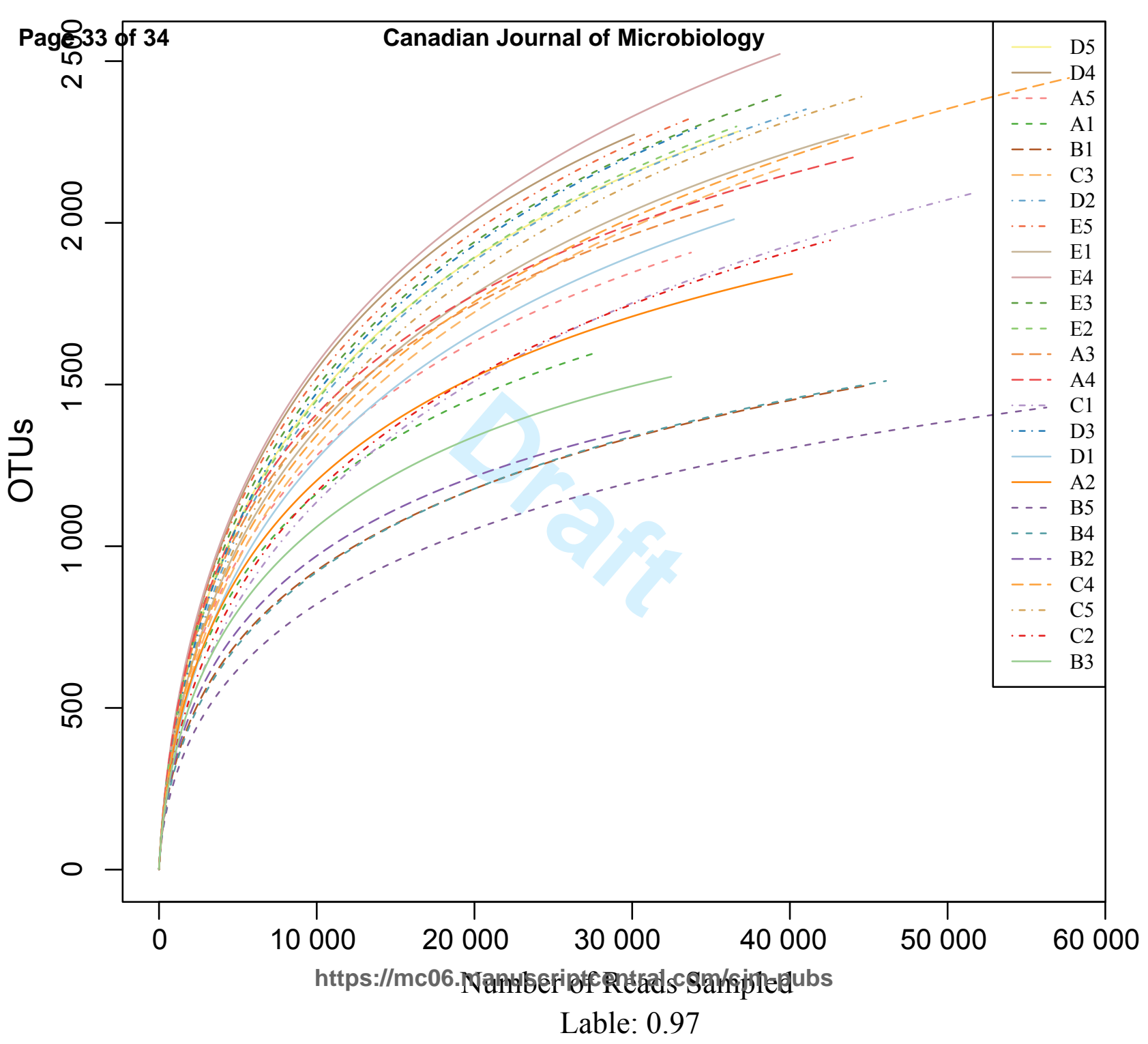




\section{Canadian Journal gf Microbiology}

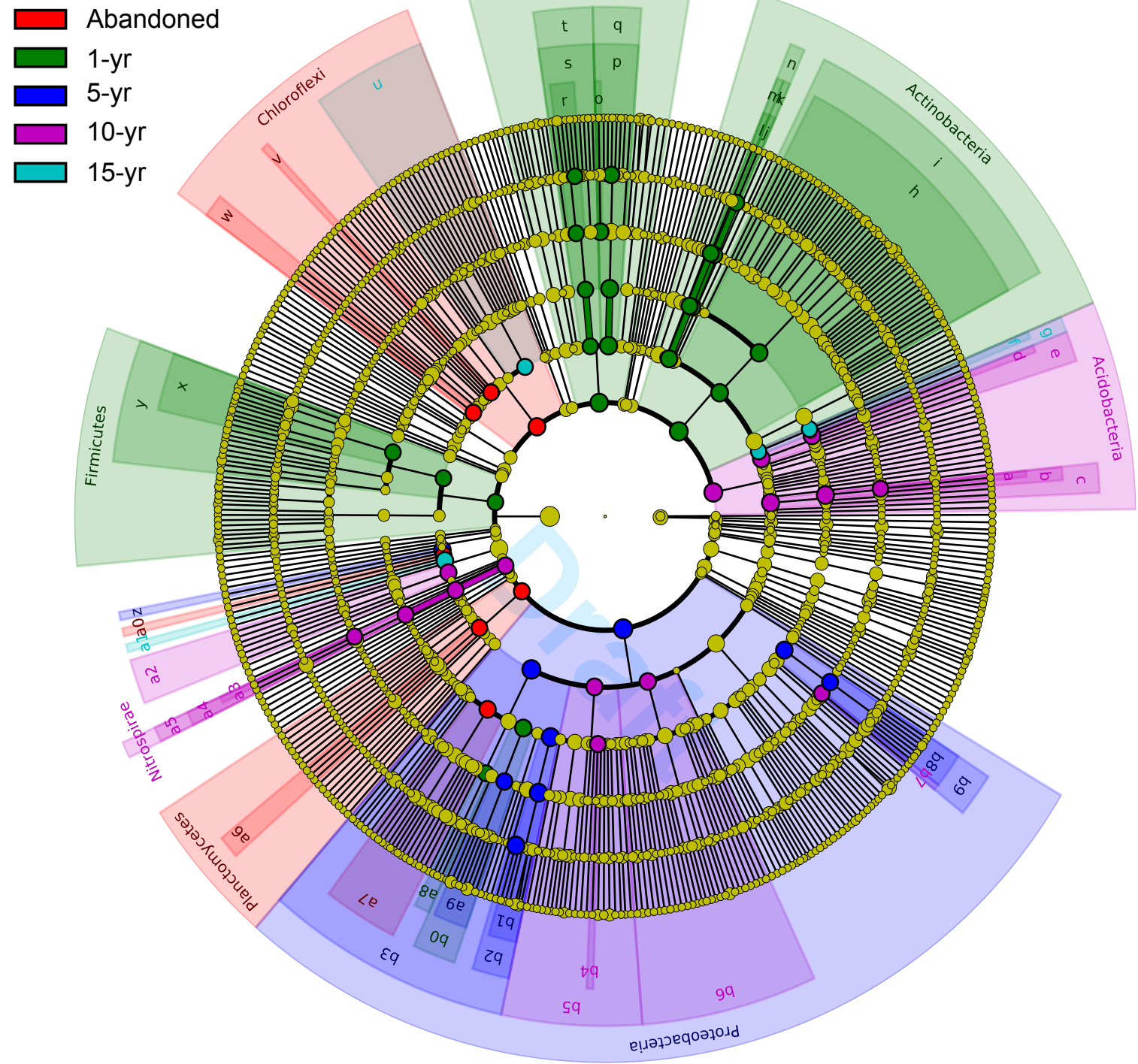

a: $\mathrm{mb} 2424$

b: iii1 15

c: Acidobacteria 6

d: RB41

e: Chloracidobacteria

f: DS 18

g: iii__8

h: Actinomycetales

i: Actinobacteria

j: Euzebyaceae $\square$ k: Euzebyales

$\square$ I: Nitriliruptoraceae

$\square$ m: Nitriliruptorales

$\square$ n: Nitriliruptoria

$\square$ o: Flammeovirgaceae

p: Cytophagales

$\square$ q:Cytophagia 2 ito

s: Flavobacteriales t: Flavobacteriia

$\square$ u: Anaerolineae

$\square$ v: Gitt_GS_136

w: Thermomicrobia

x: Bacillales

$\square$ y: Bacill

ư Tis:Gerniptcentral a1: Gemm 5 a2: Gemmatimonadetes

a3: 0319 6A21

4: Nitrospirales

a5: Nitrospira

a6: Phycisphaerae

a7: Rhizobiales

a8: Rhodobacteraceae

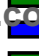
ag: Rhodospipraceae b0: Rhodospirillales b1: Sphingomonadaceae b2: Sphingomonadales

b3: Alphaproteobacteria b4: MND1

b5: Betaproteobacteria b6: Deltaproteobacteria b7: Sinobacteraceae b8: Xanthomonadaceae b9: Xanthomonadales 